\title{
Hearing loss: Can it be neurobrucellosis?
}

\author{
Hacer Aktürk1', Asuman Özkan², İlkay Özmeral Odabaşı1', Tuğçe Uzunhan³, Nezahat Gürler², \\ Oğuz Bülent Erol ${ }^{4}$, Nuran Salman ${ }^{1}$, Ayper Somer ${ }^{1}$ \\ ${ }^{1}$ Department of Pediatric Infectious Diseases, Istanbul University Istanbul Medical Faculty, Istanbul, Turkey \\ ${ }^{2}$ Department of Medical Microbiology, Istanbul University Istanbul Medical Faculty, Istanbul, Turkey \\ ${ }^{3}$ Department of Pediatric Neurology, Istanbul University Istanbul Medical Faculty, Istanbul, Turkey \\ ${ }^{4}$ Department of Radiology; Istanbul University Istanbul Medical Faculty, Istanbul, Turkey
}

\begin{abstract}
Brucellosis is a zoonotic infection transmitted from animals to humans mostly by ingestion through infected food products, direct contact with an infected animal. It can involve any organ system and present with a broad spectrum of clinical findings. Central nervous system involvement, so called neurobrucellosis, is rarely seen in pediatric age population. Neurologic manifestations may also show great variability and lead to confusion in diagnosis. Here, we report a case of chronic neurobrucellosis presenting with gradually worsening sensorineural hearing loss and subsequently developed meningitis. A 15 years old girl was diagnosed as neurobrucellosis with the aid of positive serum and CSF agglutination tests, in addition to clinical findings and positive exposure history to unpasteurized dairy products. Clinicians serving in endemic areas should consider brucellosis in differential diagnosis of such atypical clinical presentations to avoid delay in diagnosis and treatment. J Microbiol Infect Dis 2015;5(3): 125-128
\end{abstract}

Key words: Hearing loss, neurobrucellosis, meningitis.

\section{İşitme kaybı: Nörobruselloz olabilir mi?}

\section{ÖZET}

Brusella, insanlara çoğunlukla enfekte yiyeceklerin yenmesiyle veya enfekte hayvan ile doğrudan temas yoluyla geçen bir zoonozdur. Her organ sistemini tutabilir ve buna bağlı olarak çok çeşitli klinik bulgularla ortaya çıkabilir. Çocukluk çağında merkezi sinir sistemi tutulumu nadirdir. Nörolojik bulgular da çeşitlilik gösterebilir ve bu durum tanıyı güçleştirebilir. Burada giderek ilerleyen çift taraflı sensorinöral işitme kaybı ve sonrasında gelişen menenjit ile başvuran bir nörobruselloz vakası sunuldu. On beş yaşındaki kız çocuğuna, klinik bulguları ve pastörize edilmemiş süt ve süt ürünü alımı öyküsüne ek olarak serum ve BOS aglutinasyon testlerinin pozitif sonuç vermesiyle nörobruselloz tanısı konuldu. Brusellozun endemik olduğu bölgelerde çalışan hekimlerin benzer şekilde atipik belirtilerle başvuran hastalarda nörobrusellozu akılda tutması tanıda gecikmelerin önlenmesi açısından önemlidir.

Anahtar kelimeler: İşitme kaybı, nörobruselloz, menenjit

\section{INTRODUCTION}

Brucellosis is a zoonotic infectious disease that is common in certain geographic areas, namely in Mediterranean countries and the Middle East. It is transmitted to humans mainly by consumption of infected animal products or direct contact with secretion of infected animals. It can affect any organ system in the body, with a great diversity in clinical course resulting in difficulty and delay in diagnosis. ${ }^{1}$
Central nervous system (CNS) involvement, so called neurobrucellosis (NB) is reported in only 5\% of cases. ${ }^{1}$ Its frequency is found to be even lower in pediatric age population. Pediatric case series from Turkey reported an incidence of $<1-2.2 \%{ }^{2,3} \mathrm{NB}$ may lead to such complications as acute or chronic meningitis, meningoencephalitis, myelitis, intracerebral abscess, demyelination and cranial nerve involvement. ${ }^{4,5}$ We reported here a rare case of neurobrucellosis presented with a chronic course of hearing loss and subsequent meningitis. 
Case: A 15 years old girl was referred to pediatric emergency room with complaints of progressive gait disturbance and fatigue. Although mentioning a vague fatigue and weakness for about previous 1 year, she defined bilateral tinnitus that appeared 9 months ago as a first distinct complaint. Four months later, she had developed hearing loss on the left ear. Because a gradual hearing loss was also realized on the right ear, she was admitted to an otology department of a private hospital 3 months ago. She had been advised to use a hearing aid, with no benefit. She had lost hearing on the right ear as well, and subsequently was given a three-courses of methylprednisolone pulse therapy. Because a gait disturbance and increase in fatigue appeared on the fourth day of this therapy, her parents took her to another hospital. She was evaluated there and found to have severe bilateral sensorineural hearing loss (SNHL) revealed by auditory brain stem response study, and then referred to our hospital.

She lived in eastern part of Turkey, with unremarkable personal and familial medical history. On admission, she was conscious but barely cooperated due to bilateral hearing loss. The physical examination showed a body weight of $42 \mathrm{~kg}$ (50th percentile), a height of $155 \mathrm{~cm}$ (50th-75th percentile), a body temperature of $37.4 \mathrm{oC}$, a blood pressure of $100 / 60 \mathrm{mmHg}$, a rhythmic pulse rate of 80 per minute and a respiratory rate of 18 per minute. On neurological examination, she had nuchal rigidity, ataxic gait, dismetria and intentional tremors on bilateral hands. Deep tendon reflexes were increased and plantar reflexes were extensor with clonus. There was a mild motor deficit of lower extremities with a degree of $4 / 5$.

Complete blood count and routine biochemical tests were in normal limits. Erythrocyte sedimentation rate was $25 \mathrm{~mm} /$ hour and $C$ reactive protein was $0.1 \mathrm{mg} / \mathrm{dL}$ (vs. normal value of $0-5 \mathrm{mg} / \mathrm{dL}$ ). Cerebrospinal fluid (CSF) examination revealed a glucose value of $16 \mathrm{mg} / \mathrm{dL}$ (synchronous blood glucose: $90 \mathrm{mg} / \mathrm{dL}$ ) and a protein value of $823 \mathrm{mg} / \mathrm{dL}$. Microscopic evaluation of CSF identified 346 lymphocytes $/ \mathrm{mm} 3$ and 91 polymorphonuclear leucocytes/mm3. No microorganism was detected in CSF Gram and acid fast bacteria staining. She was given ceftriaxone and antituberculous treatment with four drugs. CSF polymerase chain reaction (PCR) testing was negative for Herpes simplex virus type 1 and Mycobacterium tuberculosis. No evidence of cryptococcal infection was found after Indian ink staining. On acid fast staining of gastric lavage on 3 consecutive days, no mycobacterium was de- tected. Serologic evaluations of other possible infections such as mycoplasma, cytomegalovirus, Epstein-Barr virus and Borrelia burgdorferi found to be negative. Cranial magnetic resonance imaging (MRI) showed widespread contrast enhancement of leptomeningium, from the periphery of the lateral ventricles to the lumbar area. She lived in an area in which stockbreeding is common and a special kind of a fresh cheese reputed to be herbaceous cheese is consumed very frequently. On detailed history the patient approved the consumption of such dairy products. Serologic tests confirmed the diagnosis of neurobrucellosis: serum agglutination test (SAT) was positive at $1 / 80$, serum Coombs' agglutination test, carried out to detect blocking antibodies by using anti-human gamma globulin sera was positive at 1/320; CSF agglutination test was positive at $1 / 40$, CSF Coombs' agglutination test was positive at $1 / 160$. Antituberculous drugs were ceased. Doxycycline, rifampicin and gentamicin were added to ceftriaxone. CSF examination repeated on forth week of treatment revealed normal results. Then she was discharged with treatment of doxycycline and rifampicin. Combination therapy was continued for six months. On follow up, all clinical abnormalities were completely resolved other than bilateral hearing loss.

\section{DISCUSSION}

Neurobrucellosis may present with various neurological manifestations, one of them being cranial nerve involvement. Although there are reports indicating paralysis of optic, oculomotor, facial and abducens cranial nerves, there seems to be a predilection to vestibulocochlear nerve. ${ }^{6-11}$ We reported in this paper a chronic neurobrucellosis case starting with a gradually increased hearing loss and leading to meningitis within a period of 9 months.

Especially in chronic infections, diagnosis of NB may be missed, because it may mimic any other infectious and/or inflammatory disease or may appear as a subclinical presentation. Likewise, our case had been complaining about weakness for 1-2 years, as a subclinical presentation of Brucella infection. Afterwards, she had developed a gradually worsening hearing loss starting from 9 months ago. Subsequently, neurological symptoms appeared as a manifestation of meningitis 1 month before her admission to our hospital. This chronic and atypical clinical picture has led to a delay in diagnosis and treatment. 
Vestibulocochlear nerve can be affected in NB leading to SNHL. ${ }^{9-11}$ Since it can appear as single manifestation of the disease, SNHL should be realized as a probable clinical presentation of brucellosis by otologists and neurologists, to whom these patients admit first. ${ }^{12}$ Earlier recognition of SNHL as a manifestation of brucellosis would have prevented the progression of hearing loss and development of meningitis in our case.

Diagnosis of neurobrucellosis requires firstly demonstration of meningeal inflammation either by meningeal irritation signs, reported to be present in only $\% 27 .{ }^{3}$ of cases in a case review or meningeal contrast enhancement on cranial MRI. ${ }^{13}$ Abnormal CSF findings and direct or indirect evidence of Brucella in CSF establishes the definite diagnosis. CSF analysis in Brucella meningitis reveals elevated protein, low or normal glucose and lymphocyte pleocytosis. ${ }^{4,13}$ Isolation of Brucella from the blood was reported to be $15-70 \% .{ }^{14}$ The rate of isolation from CSF was found to be even lower, less than $<20 \%$ of the cases in a report. ${ }^{15}$ Serum agglutination test, which is most commonly used test for diagnosis of Brucellosis, detects antibodies against Brucella abortus, Brucella suis and Brucella melitensis. ${ }^{4} \mathrm{~A}$ serum agglutination titer greater than $1 / 160$ and a CSF agglutination titer greater than $1 / 80$ is considered as diagnostic for Brucellosis. ${ }^{1,4}$ In the present case, NB was suspected by history of consuming untreated dairy products, clinical course, presence of neck stiffness and other neurological findings, widespread leptomeningeal contrast enhancement on MRI, CSF findings of low glucose, high protein and lymphocytic pleocytosis. Finally, a definite diagnosis was made by demonstration of a positive serum and CSF agglutinin titer.

Treatment regimen and duration is still an issue of debate in neurobrucellosis. Nevertheless, use of doxycycline in combination with rifampicin and/ or trimethoprim/sulfamethaxasole (TMP/SMX) and an aminoglycoside for the first 14 days is generally recommended. ${ }^{4,5}$ Since aminoglycosides do not penetrate well into CSF, ceftriaxone were also used for the first two weeks in some reports. ${ }^{5,13}$ Reviewing the literature revealed that treatment was continued thereafter by combination of doxycycline plus rifampin and/or TMP/SMX for a duration of three months to one year. ${ }^{5,13}$ It seems reasonable that duration of treatment should be individualized, since some patients may require longer courses. ${ }^{5}$ Our patient received firstly ceftriaxone and 4-drug regimen of antituberculous treatment, because Turkey is also endemic for tuberculosis and the clinical picture together with results of CSF analysis were also indicating tuberculous meningitis. After we made the diagnosis of NB definite and ruled out TB by negative PCR, culture and acid fast staining of CSF, antituberculous drugs was discontinued and doxycycline, rifampicin and streptomycin were added to ceftriaxone treatment. Two weeks later ceftriaxone and streptomycin was also ceased, continuing with doxycycline and rifampicin for 6 months.
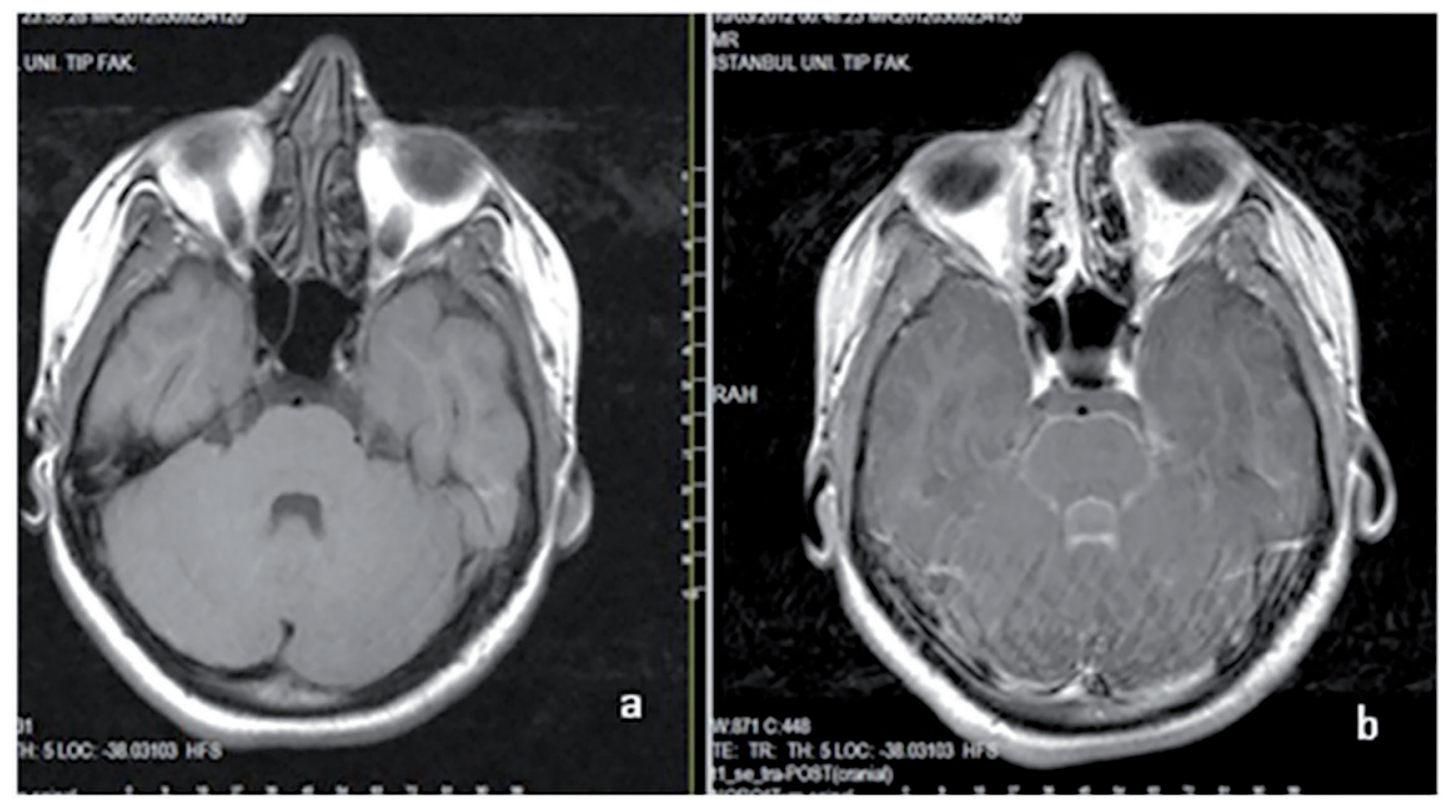

Figure 1. Axial T1 weighted MR image before (a) and after (b) contrast administration shows basal meningeal and ventricular enhancement. 


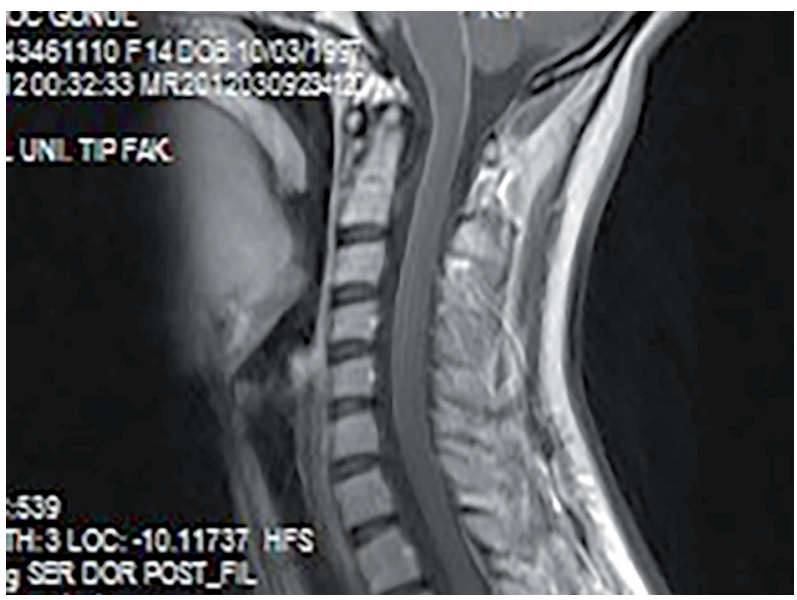

Figure 2. Sagittal T1 weighted and contrast-enhanced image of cervical spine showing diffuse leptomeningeal involvement.

Brucella meningitis generally has a good prognosis, an important feature differentiating it from other infections causing chronic meningitis. Brucella meningitis has a low mortality rate and responds well to medical treatment with mostly complete recovery from neurological deficits. ${ }^{13}$ Permanent deficits have also been reported in a limited number of patients. ${ }^{5,13}$ Although there are reports documenting improvement in hearing after successful antimicrobial therapy, SNHL is mostly an irreversible complication of brucellosis., ${ }^{9,11,12}$ In conformity with the literature, neurological status of our patient improved completely, but hearing did not recovered.

In conclusion, clinicians serving to patients from endemic areas of Brucellosis should be aware of its atypical clinical presentations, like SNHL. This is a report indicating importance of the need to include serological tests for brucellosis in the routine diagnostic screening for $\mathrm{SNHL}$ in endemic areas.

\section{REFERENCES}

1. Pappas G, Akritidis N, Bosilkovski M, Tsianos E. Brucellosis. N Engl J Med 2005;352:2325-2336.

2. Tanir G, Tufekci SB, Tuygun N. Presentation, complications, and treatment outcome of brucellosis in Turkish children. Pediatr Int 2009;51:114-119.

3. Lubani MM, Dudin KI, Sharda DC, et al. A multicenter therapeutic study of 1100 children with brucellosis. Pediatr Infect Dis J 1989;8:75-78.

4. Young EJ. Brucellosis. In: Feigin RD, Cherry MD, Demmler GJ, Kaplan SL (eds). Textbook of Pediatric Infectious Diseases (Vol. 1, 6th ed). Philadelphia: Saunders; 2009:16781683.

5. McLean DR, Russell N, Khan MY. Neurobrucellosis. Clinical and therapeutic features. Clin Infect Dis 1992;15:582-590.

6. Işıkay S, Yılmaz K, Ölmez A. Neurobrucellosis developing unilateral oculomotor nerve paralysis. Am J Emerg Med 2012;30:2085.e5-7.

7. Karakurum Goksel B, Yerdelen D, Karatas M, et al. Abducens nerve palsy and optic neuritis as initial manifestation in brucellosis. Scand J Infect Dis 2006;38:721-725.

8. Tonekaboni SH, Karimi A, Armin S, et al. Neurobrucellosis: a partially treatable cause of vision loss. Pediatr Neurol 2009;40:401-403.

9. Ucmak H, Kokoglu OF, Kirecci E, et al. Hearing loss and accompaning disturbance of Neurobrucellosis cases. Pakistan Journal Of Medical Sciences, 2012;28:556-559.

10. Guneri EA, Kirkim G, Serbetcioglu BM, et al. Cochlear implantation in neurobrucellosis. Otol Neurotol 2009;30:747749

11. Cagatay A, Karadeniz A, Ozsut $\mathrm{H}$, et al. Hearing loss in patient with neurobrucellosis. South Med J 2006;99:1305-1306.

12. Coskun O, Ertem GT, Ergun U, et al. Evaluation of brainstem auditory potential in brucellosis patients with and without neurological involvement. Int J Neurosci 2005;5:717-723.

13. Yetkin MA, Bulut $C$, Erdinc FS, et al. Evaluation of the clinical presentations in neurobrucellosis. Int $\mathrm{J}$ Infect Dis 2006;10:446-452.

14. Mantur BG, Akki AS, Mangalgi SS, et al. Childhood brucellosis: a microbiological, epidemiological and clinical study. J Trop Pediatr 2004;50:153-157.

15. Araj GF, Lulu AR, Saadah MA, et al. Rapid diagnosis of central nervous system brucellosis by ELISA. J Neuroimmunol 1986;12:173-182. 